\title{
浅议小学中高年级学生将“做中学”策略融入 3D 打印学习的方法
}

\author{
肖永平 \\ 六盘水市钟山区第二实验小学 \\ D O I:10.32629/jief.v2i1.459
}

[摘 要] 3D 打印教育在近年来的国际教育研究和实践中展现出了很多优点, 结合目前国家重视人工智能教育的发展现状, 在学校课题研究 活动中主要以小学中高年级学生学习 3D 打印实践情况的分析为主, 让学生掌握做中学的思想, 探究适合学校开展 3D 打印创意设计的方法, 并且在借鉴的基础上再结合本校开展的科技活动，探索更加适合小学中高年级学生开展 3D 打印的教学模式。

[关键词] 做中学 ; 3D 打印 ; 融入 ; 学习模式

做中学是基于动手探究的一种科学学习方法, 探究式的科学教育是 在教师的引导下以学生为主体的学习过程, 让学生亲自参与对科学现象的 探究, 让他们通过观察与实验, 接触生活实际, 从而激发学生探究学习科 学的主动性和想象力, 在做的过程中学习。

3D 打印创意设计的过程是先通过计算机建模软件建模, 再将建成的 3D 模型 “分区” 成逐层的截面, 即切片, 设计软件和打印机之间协作的标准 文件格式是 STL 文件格式, 从而指导 3D 打印机逐层打印所设计的作品。

1 将做中学探究学习方式融入 3D 打印社团活动中

学校的社团活动是学生在课余充分张显自己个性的课堂, 学生在自 己选择的社团活动中能培养学生的大胆创新能力, 挖掘学生内在潜力有 利, 开展社团活动对减轻学生课外负担有利, 学校开展社团活动, 使学生 在自己的社团活动中充分发挥自己的优点 ${ }^{[1]}$ 。社团活动中将 “做中学” 的 探究性学习方式融入让学生认识到探究性的重要性, 在 3D 打印学习中, 不可能每种设计都需要教师给学生讲授, 学生在教师的引导初步学会一些 3D 打印设计方面的知识后, 大部分时间都是社团活动中让学生自己进行 探究, 学生各种创意的想法就能得到体现。如在学校举行社团活动中, 在 我们的课题《小学中高年级将 “做中学” 策略融入 $3 \mathrm{D}$ 打印学习的研究》 研究中, 我们课题实验教师都是引导学生利用 3Done 软件来设计 $3 \mathrm{D}$ 模型, 在学生认识 3Done 中一些常用的命令后, 让学生自己在社团活动中进行探 究式学习, 教师只是作一些学生不明白地方的指导。

2 学生亲自实践, 打印自己精心设计的作品提高学习兴趣

实践活动在我们的社团活动中起着至关重要的作用, 实践活动对培 养学生的能力是一个不可缺少的环节, 理论上学习是否正确, 学生在社团 活动中的创意设计是否合理, 都需要实践来验证。脱离了实践的验证, 那 么学生的作品设计可能会在在打印过程中出现一些不可避免的问题, 做中 学的理论就是强调学生自己做过的自己不会忘记, 学生只有在实践活动中 才能激发他们的探究欲望, 才能加深对探究知识的理解, 在学生实践活动 中, 努力采用合理的引导学生学习的探究学习方法, 帮助学生构建认知结 构, 从整体上提高学生的综合实践能力, 唤起学生主动探究的意识, 让学生 主动地参与到学习中来, 使学生乐学 ${ }^{[2]}$ 。如在课题研究过程中, 我们都要 求参加社团学习的学生都要打印一份自己的 3D 作品, 由于打印每件作品 的时间都比较长, 学校参加这项目活动的学生又多, 让学生打印一件简单、 家长也能看得到的 “移车电话”, 学生在打印的过程中才知道自己所设计的 作品底部是厚了还是薄, 打印要花多少时间, 并且有些学生在设计电话时 不是直接在一个平面上设计一个简单的电话, 而是通过 3Done 中的拉伸命 令, 将电话变成立体的形状, 这就充分体现出社团活动的学生不同的创造 能力, 并且家长也能看到学生参加的这项活动时所创作的作品后就会很支 持自己的孩子参加 $3 \mathrm{D}$ 打印这项活动, 这项活动才能得以在学校进行推广。

3 充分利用课题研究, 探寻适合学生的教学模式。

我国对 “做中学” 教育的学术关注点主要集其课程研究、教育理念 及实践案例, 将 $3 \mathrm{D}$ 打印作为开展创客教育的主要教学模式, 目前存在的
现状是在教育模式方面, 缺少将 “做中学” 策略与 3D 打印融合的学习方 法, 到目前为止, 还需要让学生在学习探索 $3 \mathrm{D}$ 打印课程中找到更适合小 学中高年级的学习模式。在课题研究中将研究重点放在课堂教学设计上, 对如何进行 “3D 打印” 课堂类型的划分, 采取什么样的上课形式, 以及 怎样进行有效的教学设计来提高教学效果进行了深入的研究, 将课题研究 的过程中可以借鉴一些研究方法运用到社团活动中, 寻求适合学生发展的 教学模式。

4 在社团活动中学生之间进行小组合作, 互相帮促

新的教学理念倡导学生 “自主学习、小组合作”, 强调以学生为主体, 在小组合作过程中, 让每一个学生在讨论过程中都有机会发表自己的观 点, 小组合作、互助学习就成为 $3 \mathrm{D}$ 打印学习过程中的一种学习模式 ${ }^{[3]}$ 。

“做中学” 也很强调小组合作的学习模式, 学生在活动过程进行交流, 讨论, 才能更好设计出自己的 3D 打印作品, 在社团活动中, 有高年级的 学生报名参与, 也还有少数是才接触电脑知识的一些三年级学生, 这部分 学生是学习 $3 \mathrm{D}$ 打印及比赛的后备力量, 他们对电脑的操作水平及认知水 平不能和高年级学生相比, 在学习过程中我们采用让这高年级学生对他们 实行一对一或者一对多的帮助, 这些小讲师在帮助其他同学时不断提升自 己对制作 3D 作品 3Done 软件的熟悉程度, 这样的学习模式大大减轻了社 团辅导教师的工作量, 在社团活动中我们还专门请曾经参加过省赛、市赛 取得不错成绩的学生担任小讲师的角色, 让他们担任培训, 辅导教师给一 个下节社团课要制作的作品, 每次授课后都会选择 1-3 名学生回家作好 准备, 或者让他们进行小组合作先进行讨论交流, 在下次课时进行给其他 学生进行培训。

在课题开展的过程中, 课题组在准备阶段结合已经取得一些成绩的 经验, 觉得将做中学策略融入到 $3 \mathrm{D}$ 打印活动中, 让学生在做的过程中学 习, 在社团活动中还培养部分小讲师, 利用本地科技活动作为地方资源, 带领社团的学生参加贵州省、六盘水市举行的创客比赛及 3D 打印创意设 计, 让学生在这些科技活动中通过参赛不断提高自己在赛场上的经历, 利 用比赛中自己取得的成绩建立学习上的自信, 这些教学模式还需要在课题 后期的研究中进一步进行论证。

\section{[参考文献]}

[1]高景芳.浅谈农村小学开展社团活动的必要性 [J].中华少年 : 科学 家 2015(24):244- 245.

[2]王雅婧.浅谈小学综合实践活动中学生自主探究能力的培养 [J]. 学苑教育,2017(12):18-18.

[3] 易俊英. 《活动指导》课程中的小组合作 [ J].科学咨询 : 科技. 管 理,2014(5):99-100.

作者简介: 肖永平 (1977- ), 男, 汉族, 贵州钟山人, 大专, 一 级教师 (小)，长期从事在小学科学教学活动中利用“做中学”策略 培养学生的动手实践能力的研究, 现尝试将“做中学”的探究式学习 方法融入到学生 3D 打印学习过程中。 